\title{
Economics of Farm Resource Utilization in River Nile State of Northern Sudan
}

\author{
Elgilany Ahmed*, Jamalludin Sulaiman, Saidatulakmal Mohd \\ School of Social Sciences, University Sains Malaysia, Pulau, Penang, 11800, Malaysia
}

\begin{abstract}
In Sudan, land tenants use numerous crops to intensify production in an attempt to improve household food security and income. Resources-use optimization is critical to produce field crops which are regarded as essential food and cash crops in Sudan. This paper looks at River Nile State of north Sudan as a case study due to its high potential to grow food and cash crops. The crops are commonly produced under pump irrigation from the River Nile. Production of these crops in the State faces nume rous hindrances, including ineffic iency of resources utilization, low level of productivity and high cost of production. The research aimed to optimise the use of available resources in food and cash crops. Primary data were collected using structured questionnaires on 70 randomly selected respondents. A linear programming technique was used to assess the optimal combination of resources in the crops under study. The model revealed that tenants would get higher returns by optimising resource utilization in food and cash crop production. The State tenants should therefore be guided on how to optimally utilize their resources and be encouraged to grow cash and food crops as a significant contribution to farm sustainability and malnutrition alleviation.
\end{abstract}

Keywords Economizing Resources Use, Yield Improvement, Increasing Farm Income

\section{Introduction}

Sudan's economic structure has undergone a major shift over the past two decades[5], the main drivers being oil discovery at the turn of this Century and expansion in services. An overwhelming proportion of the nearly two-thirds of the Sudanese who live in rural areas depend on agriculture for their livelihood. About $70 \%$ of the labour force is principally employed in agricultural sector. It is evident that in the fores eeable future the welfare of Sudan's population, especially of the poor who are largely located in rural areas, will to a substantial degree depend on the performance of the agricultural sector[11]. Agriculture has almost consistently been disadvantaged in public allocations to various economic sectors[6]. Its allocations are both meager and dwindling: from $3.4 \%$ to $1.6 \%$ during 2000 to 2005 (by more than 50\%). The actual share of agriculture in the total development expenditure varied from $8 \%$ to $44 \%$ over the period 2000 to 2005 , but the trend is irregularly increasing. Higher shares were allotted to agriculture within actual expenditure on the overall national development programs ranging from $21 \%$ to $46 \%$; yet also with irregular distribution among years (Faki et al, 2009). Agricultural production in Sudan is hampered by high production costs

* Corresponding author:

elgilanya@yahoo.com (Elgilany Ahmed)

Published online at http://journal.sapub.org/re

Copyright (C) 2012 Scientific \& Academic Publishing. All Rights Reserved especially the irrigated one, excessive taxation particularly for livestock, high costs of provision of services, and charges that are not connected with the provision of any services.

This paper aims to assess the interrelation between agricultural deterioration and poverty incident in rural area. Finally, economic activities in public and private sectors, development interventions and commodity movement have been quite restricted. Under such a situation agricultural constraints and poverty incident would obviously be expected to escalate. The main findings of this paper indicated strong relationship between the agricultural dimin ishing and poverty incidence in rural area. Accordingly, the research seeks to draw a road map of agricu ltural re forms, State policies and public investments in agriculture.

\section{Methodology}

This study depends main ly on primary data from the study area, beside secondary data from relevant official sources. The method selected for primary data collection was direct personal interviewing of the sample respondents by using structural questionnaires. The primary data collected in 2006 included demographic and socioeconomic characteristics of the surveyed tenants, agricultural production and factors affecting irrigation water-use. Secondary data was collected fro $m$ relevant institutional sources.

\subsection{Anal ytical Techniques}


To achieve the stated objectives, descriptive statistical analysis using Cobb-Douglas production functions with Ordinary Least Square (OLS) regression to ass ess the effect of the hypothesized independent variables on water use efficiency. The calculation of the crop water requirements (CW R) was achieved through FAO software program CROP WAT4 according to the recommended Penman- Monteith formula as follow:

$$
\text { ETo }=C\left(\mathrm{WR}_{\mathrm{n}}+(1-\mathrm{W}) \mathrm{f}(\mathrm{u})(\text { ea-ed })\right.
$$

Where:

$\mathrm{W}=$ weighting factors

$\mathrm{R}_{\mathrm{n}}=$ net radiation

ea $=$ saturation pressure

ed $=$ perfumed water

$\mathrm{f}(\mathrm{u})$ = function in wind speed

$\mathrm{C}=$ error factor

LP technique was used to achieve the optimal solution for field crops of the crop combination in Elzeidab farming system. From the collected data, the average farm resources, yield and gross margins by feddan were computed and entered in the General A lgebraic Modeling System (GAMS) software program for optimization analys is. The model was specified with gross margins maximization as the objective function as:

$$
\operatorname{Max} \mathrm{Z}=\sum \underset{\mathrm{j}=1}{\mathrm{Cj}}
$$

Such that:

$$
\sum \alpha \mathrm{ijXj} \leq \mathrm{bi}, \text { all }={ }_{\mathrm{j}=1}^{\mathrm{n}} \text { to } \mathrm{m}
$$

And:

$$
X j \geq 0 \text {, all } j=1 \text { to } n
$$

Where:

$\mathrm{Z}=$ objective function value.

$\mathrm{Xj}=$ Level of the $\mathrm{jth}$ the farm activity. Let $\mathrm{n}$ denote numbe of possible activities; the $\mathrm{j}=1$ to $\mathrm{n}$.

$\mathrm{Cj}=$ Objective value, in this case the forecasted feddan) gross marg in of a un it of the jth activity (SDD per feddan) Aij = quantity of the ith resource available required to produce one unit of the jth activity

$\mathrm{M}=$ Denote the number of resources; then $\mathrm{i}=1$ to $\mathrm{m}$

$\mathrm{Bi}=$ A mount of the $1^{\text {th }}$ resource available (e.g. cubic meter of water).

\section{Results and Discussion}

\subsection{Socioeconomic Char acteristics of the Tenants}

The socioeconomic characteristics of the tenants are expected to have a great effect on the production process in the study area. In addition to increasing crop production and farm and family incomes, improved irrigation access significantly contributes to rural poverty reduction through improved employment and livelihood within a region[2]. The main collected socioeconomic information was on tenants' education level, marital status, age, family size, family contribution on field work, years of experience, occupations in and/or out farm, distance between the tenants' home and field, farm size of tenants, and land tenure beside some data regarded their farm activities. From Table 1 the major socioeconomic characteristics of Elzeidab that all farmers in the sample are males and $85.7 \%$ were married and $14.3 \%$ of the $m$ were single.

Table 1. Major socioeconomic characterist ics of the surveyed tenants

\begin{tabular}{|c|c|c|c|}
\hline No. & Indicator & Mean & ST D \\
\hline 1 & Age & 39.9 & 9.8 \\
\hline 2 & Family size & 6.5 & 3.2 \\
\hline 3 & Years of experience & 19.9 & 12.3 \\
\hline 4 & Farm size & 8.2 & 6.9 \\
\hline 5 & $\begin{array}{c}\text { Distance from tenants' } \\
\text { resident to the farm }\end{array}$ & 2.7 & 3.2 \\
\hline 6 & Number of family labor & 2.0 & 1.8 \\
\hline
\end{tabular}

\subsection{Production of Food and Cash Crops}

Although most of the crops grown in the State are mostly highly profitable, limitations on land, water, labour and capital hinder attainment of adequate benefits. Most of the land $(48 \%)$ is allocated to cereals followed by legumes $(22 \%)$. A diversity of vegetables, spices and fodder crops occupy small areas. Crop yields were much lower than research yields. Yield gaps of $47 \%$ and $81 \%$ were derived for dry beans and vegetables, respectively, indicating high potential to boost yields. According to Peter (2000), every $10 \%$ increase in crop yield reduces the number of income-poor by an average $7.2 \%$ in Sub-Saharan Africa. Variables cost of production play a unique role in producing annual crops where material-input costs largely influence earned profits[4]. The survey revealed that about 15 components constitute most of the production cost. Most respondents complained about the high cost of production due to high cost of production inputs. Irrigation water is considered as the single most expensive resource due to the high cost of water pumping from the River Nile. However, sampled farmers invariably over-irrigated their annual crops (Figure 1), with crop water requirements exceeded annually by $60 \%$.

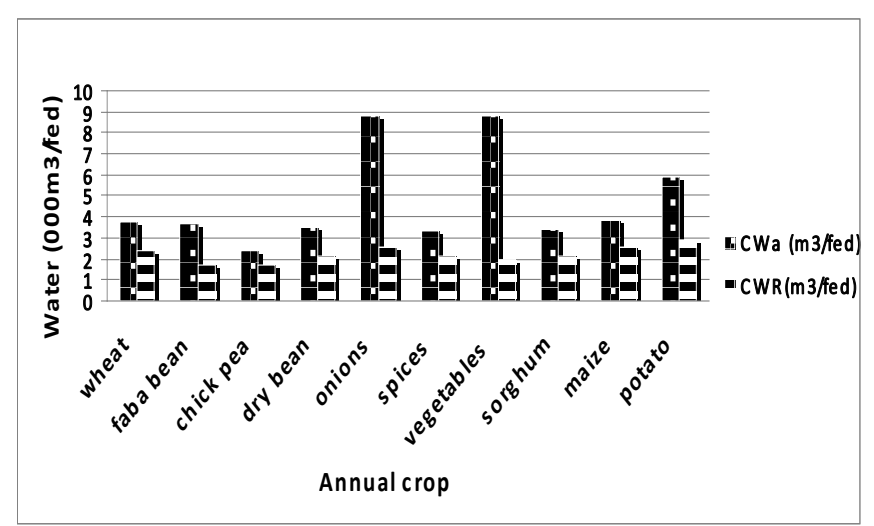

Figure 1. Physical gaps between crop water requirements (CWR) and applied crop water (CWA) for the crops under study

This suggests high potential for water use (e.g. for additional crops) once water-use efficiency is improved. Labour is also an important resource, but tenants tended to 
avoid using hired labour to reduce production costs. On average, tenants employed two family members; however (for example), 10 and 34 work-days of hired labours are recruited for chickpea and potato production, respectively. After land, water and labour, the fourth pillar of production is capital. The formal financial system provides only a small part of the credit used by farmers and $93 \%$ of the surveyed tenants depended on their own resources, while informal sources such as village merchants contributed only $2.8 \%$.

\subsection{Importance of Crops to Household Living}

Annual crops - especially wheat, sorghum, food legumes, vegetables and forages - are generally considered the main sources of food and cash crops. Moreover, they play an important role in sustaining the production of the farming systems.

Decisions on marketable surplus quantities and the timing of their sale depend on the type of crop. Given limited infrastructure, this leads to high levels of sales immed iately after harvest; however, some is withheld for disposal over the rest of the year. $88 \%$ of the produce was sold $(77 \%$ immed iately after harvest and $11 \%$ for future sales), with the remaining $12 \%$ going to storage. About $32 \%$ of the stored quantities were for next season's seeds and $68 \%$ for household consumption. Of individual crops, grains and legumes are partly sold after harvest and partly stored, while vegetables, spices and potatoes are sold immediately due to lack of appropriate storage infrastructure and inadequate markets as illustrated in Table 2.

Table 2. Distribution of annual crop quant ities

\begin{tabular}{|c|c|c|c|c|}
\hline $\begin{array}{c}\text { Crop } \\
\text { Distribution }\end{array}$ & \multicolumn{2}{|c|}{ Sale (88\%) } & \multicolumn{2}{c|}{ Storage (12\%) } \\
\hline $\begin{array}{c}\text { Disposal } \\
\text { Crop } \\
\text { Quantities }\end{array}$ & $\begin{array}{c}\text { After } \\
\text { harvest } \\
\text { sale } \\
(77 \%)\end{array}$ & $\begin{array}{c}\text { Future } \\
\text { sale } \\
(11 \%)\end{array}$ & $\begin{array}{c}\text { Seeds of } \\
\text { next season } \\
(32 \%)\end{array}$ & $\begin{array}{c}(68 \%) \\
\text { Household } \\
\text { consumption }\end{array}$ \\
\hline
\end{tabular}

Most studies confirmed that diversified income sources might enhance farm sustainability. Beetz (2002) reported that, integrating trees and shrubs with the other enterprises on a farm can create additional sources of income, spread farm labour throughout the year, and increase the productivity of the other enterprises, while protecting soil, water, and wildlife. Also, the main off-farm sources in the area are remittances and contributions of family members, formal employment, trade, and other off-farm private activities (Table 3 ).

Table 3. Distribution of income sources of Elzeidab tenants'

\begin{tabular}{|c|c|c|c|}
\hline Source of income & Value (SD) & $\%$ & $\%$ of total \\
\hline Source of farm income: & $1,870,280$ & 78 & \\
Seasonal crops returns & 396,533 & 17 & \\
Perennial crops returns & 107,059 & 5 & \\
Livestock returns & & & \\
\hline Total average farm income & $2,373,872$ & 100 & 32 \\
\hline Total average off-farm income & 522,700 & & 68 \\
\hline Total average income oftenants & $2,896,572$ & & 100 \\
\hline
\end{tabular}

About $37 \%$ of the tenants earned off-farm income beside their farm income, while $63 \%$ relied only on farm returns. Most of the farm inco me accrues fro m perennialcrops (78\%). The majo rity of tenants $(63 \%)$ diversified by growing several crops at one time, often having both livestock and annual crops, and sometimes value-adding enterprises.

Enterprise diversification makes it easier for hous eholds to be more self-sufficient in terms of nutrition, livestock feed, soil organic matter and energy.

\subsection{Optimal Annual Production Obtained by RNS Model}

The integrated modelling approach was useful for linking biophysical and socio-economic factors influencing decision making on small-holder farms and evaluating trade-offs for resource use in terms of nutrient balances, labour use, food sufficiency and cash balance[8]. The agricultural background of River Nile State tenants in growing annual and perennial crops and in animal breeding offer a promising option for improving the farm system and livelihood of people in both rural and peri-urban areas. The output from the model run is the objective function value (returns), the optimal crop combination, and utilised resources accompanied by their respective marginal value productivities. The model suggested the optimal land use is chick pea and dry bean only (on 8.62 and 1.38 feddans, respectively), due to these crops' high returns when compared to other annual crops in the area of study. Actual returns from crop production were SD 399,487.28, while the optimal returns are SD 811,596.73 (a 103\% increase on current levels).

The average tenant had up to 10 feddans of land, 28,573 m3 water, 191 work-days of labour and SD 179,532 (about US\$ 870) as capital available for the cropping season. The levels at which these resources were used in food legume crops were achieved. According to these results achieved by the system are indicating that, the rest of the crops could be assessed as unfeasible unless improvements are made. However, these crops are regarded as strategic (important for food security and household income), so incentives should be provided to make them more profitable. The research designed a scenario based on model solution to confirm the importance of crops that did not appear in the optimal plan. The model was assumed that, a decline in prices is happen for both chick pea and dry beans as a dominant phenomenon in the State markets. Seasonal price variation is a normal feature of agricultural products in the State: price of food crops in general follows a common seasonal pattern. The model predicted that the decline of prices for chick pea and dry bean would lead to a fall in gross marg ins, but the marg in would remain positive. Table 3 shows the results of the new model solution. The scenario analysis here provides the changes of chick pea and dry bean prices in the optimal solution. The optimal return was SD 845,495.61, which is more than the basic solution by $112 \%$. The optimal levels of the resources used were 10 feddans (all the available land), 
17,644.94 m3 of water, 133 work-days of labour and SD $202,608.4$ of cash capital are less than the actual quantities in the basic solution. The distribution of the cultivated area per feddan was diverse, including all crops except maize (Table 3). The study concluded that the obtained results led to a conviction point that crucial manipulation is needed to stabilise resources sub-sectors to achieve food security, poverty alleviation and improve the livelihood of the farmers of the State. Staple food systems will remain dominant sources of food supply, and optimised farm activities are more dependable sources of income, crop diversification offers higher returns from resources investments and hence needed to be guided.

\section{Conclusions}

The research demonstrates that River Nile State has the opportunity to take a lead in annual crop production due to its stable and high-quality natural resources. This paper explores some of the findings of the field survey, and it describes the resources utilisation for agricultural production in term of food security and poverty alleviation. We are able to draw the following conclusions:

The farming system is dominated by wheat production which occupies $25 \%$ of the farm land.

1) The study reveals the low productivity of the annual food and cash crops that form pro mising strategic crops.

2) Surface irrigation - the dominant system in the State is regarded as inefficient and expensive.

3) Agricultural production in the State is characterized as a challenge. This might attributed to the high cost of numerous of production inputs, but irrigation water is considered as the most expensive resource.

4) The irrigation cost item of wheat production was $19 \%$ of the total cost of production - the largest overall the variable cost items.

5) Overall lack of awareness about resource use optimisation among the surveyed tenants might be due to the limitations of the extension services.

6) Annual crops in the State are well-established, diversified and economically important products.

7) The tenants of the scheme were not optimally allocating the available resources and they devoted only small portions of their farmland to the most profitable crops, especially food legumes.

Based on the foregoing conclusion and the obtained results, the study recommended that:

- The potential for food and cash crop production in the area is quite promising on account of the vast natural resources. The policy makers of the State should consider the economic use of the scarce resources to increase farm gross margins, conserve soil fertility and increase farm sustainability.

- While the expected contribution of annual crops to household nutrient intake can be promoted by diversifying and optimising farm productivity, reducing the need for purchased inputs and (eventually) developing households' market-orientation for earning additional income will be conducive to resource use optimisation contributing to hunger and poverty alleviation. This could be achieved by State intervention and application of participatory approach.

Because basic services are regarded as one of the chronic constraints facing agricultural production in the State, intervention is needed to establish infrastructure (i.e. roads, stores, processing stations).

- The study detected that the tenants considered the misuse of resources as a cost issue, while they ignored the dimension of negative environmental consequences. So, it is very important to raise the tenants' awareness of environmental issues through an efficient mechanis $m$ that can be applied by the extension system.

- The study revealed that most of the annual crops under study were considered as low-value crops. Incentives should be provided to make these crops more profitable due to their importance for food security. Relevant policies may include reducing production costs or interventions to purchase them at reasonable prices.

Appropriate combination of land, water, labour and capital resources for producing food and cash annual crops in area of the study is very important and should be well designed and applied.

\section{ACKNOWLEDGMENTS}

We are thankful to Allah Almighty for the health and the strength to conduct this study. We express our deep appreciation to our colleagues in the Agricultural Econo mics and Policy Research Centre in Sudan for their great encouragement during the study period.

\section{REFERENCES}

[1] Alice Beetz. 2002. Agroforestry Overview. Horticulture Systems Guide. Alice Beetz NCAT Agriculture Specialist Published 2002. National Sustainable Agriculture Information Services ATTRA Publication \#IP155.

[2] Barker, R.; Van Koppein B. and Shah, T. "Aglobal perspective on water scarcity and poverty: Achievements and challenges for water resource management". Colombo, Sri Lanka: International Management Institute. 2000.

[3] De Pauw, E. 2009. Preliminary results of Assessment and mapping of poverty-related natural resources in Sudan. Presented at the Workshop on "Poverty Assessment and Mapping in Sudan”, Khartoum, May 2009

[4] Doll, J.P. and Orzem, F. 1984. Theory with Application (2nd edn). New York, USA.

[5] DTIS, 2008, Sudan: Revitalizing Non-Oil Exports. Diagnostic Trade Integration Study (DTIS) for the Integrated Framework Program. Study prepared by the World Bank and other international agencies in collaboration with Sudan's Commission for WTO Affairs (CWTOA), June 2008. 
[6] Elbashier, A. and Faki, H. M., 2006, The Role of agriculture in Poverty Reduction and Food Security in the Sudan. Draft for Review (2006).

[7] Elsir, A., Idris, M. and Faki, H.H. 2004. Irrigated benchmark site project for Sudan. Project Proposal Presented at the Annual Meeting of Wheat and Food Legume Crops Committees. Wadmadni, Sudan 2004.

[8] Faki, H. M., Eltahir M. N., and Abdelaziz A. H. (2009) Poverty Assessment and Mapping in the Sudan. Joint Poverty Progress Report prepared by the Centre for Agricultural Research in the Dry Areas (ICARDA) and Agricultural Economics and Policy Research Centre (AEPRC), Agricultural Research Corporation (ARC), Sudan. Poverty Assessment in Sudan IFAD Grant 961. Final Draft of Progress Report of North Sudan.

[9] Fischer, G. 2001. Integrating biophysical and socioeconomic factors in modelling impacts of global environmental change. Paper presents examples of modelingstudies carried out at the International Institute for Applied Systems Analysis (IIASA)Present and Future of Modeling Global Environmental Change: Toward Integrated Modeling, Eds., T. Matsuno and H. Kida, pp. 271-292. (C) by TERRAPUB, 2001.

[10] MAF. 2006. Annual Report 2000 prepared and distributed by Ministry of Agriculture and Forestry, Khartoum.

[11] Peter, S. 2000. Economics of organic farming, This text is extracted from COG's Organic Field Crop Handbook. For the full text, and much more outstanding information on organic farming, you can order this book at the COG website (www.cog.ca).

[12] UNDP, 2004, Agriculture Development and Poverty Reduction in Sudan, an Analy sis of Performance, Policies and Possibilities. Final Draft Report, Revised 30 May 2004. 